\section{THE TRUE ORBIT OF THE AURORAL METEOROID OF NOVEMBER I7, 1882}

A FTER many fruitless efforts to conciliate the appaA rently widely diverging data, given by the numerous observations of this most interesting phenomenon; and after having been many times on the same point as Mr. H. D. Taylor (vol. xxvii. p. 434), who has given the furst approximate calculations of this orbit, namely, "to give up the reconciling of such contradictory evidence," I have devoted my Easter holidays to new research on the true orbit. Besides the encouraging letters received from some of the English observers, I found still another motive in the observation of $\mathrm{Mr}$. Julius Dupire at Laon (France, $\beta=49^{\circ} 34^{\prime}$ ), who had the kindness to give me ample information, for which I offer him my sincere thanks, and in the communication of the following citation, kindly given me by Prof. Ch. Muntigny, of Brussels, taken from the Bulletin de l'Obser-

\begin{tabular}{|c|c|c|c|}
\hline No. & $\begin{array}{l}\text { Place of obser- } \\
\text { vation. }\end{array}$ & $\begin{array}{l}\text { Pages of } \\
\text { NATURE, } \\
\text { vol. xxvii. }\end{array}$ & Data of observation. \\
\hline I & $\begin{array}{c}\text { York, } \\
\beta=53^{\circ} 58^{\prime}\end{array}$ & $87, \mathbf{1 4 0}, 434$ & $\begin{array}{l}\text { The centre was } 6^{\circ} \text { or } 7^{\circ} \\
\text { below the moon's centre } \\
\text { (given not directly after } \\
\text { observation); } 30^{\circ} \text { eleva- } \\
\text { tioninmeridian(probably } \\
\text { a mistake or a printer's } \\
\text { error, being in contra- } \\
\text { diction with the other } \\
\text { data). }\end{array}$ \\
\hline 2 & $\begin{array}{c}\text { Clifton (Bristol), } \\
\beta=51^{\circ} 28^{\prime}\end{array}$ & 85 & $\begin{array}{l}8^{\circ} \text { from Saturn, to the } \\
\text { right, in a line inclined } \\
45^{\circ} \text { to the horizon. }\end{array}$ \\
\hline 3 & $\begin{array}{l}\text { Old Windsor, } \\
\beta=5^{1^{\circ}} 30^{\prime} \text {. }\end{array}$ & 87 & $\begin{array}{l}\text { First seen a litıle S. of } \\
\text { Aldebaran; moves across } \\
\text { the moon's disk. }\end{array}$ \\
\hline 4 & $\begin{array}{l}\text { Utrecht, } \\
\beta=52^{\circ} 5^{\prime}\end{array}$ & 296 & $\begin{array}{l}\text { Aldebaran and two points } \\
\text { in the equator at } 110^{\circ} \\
\text { and } 290^{\circ} \text { R.A. }\end{array}$ \\
\hline 5 & $\begin{array}{l}\text { Zonnemaire (near } \\
\text { Zierickzee), } \\
\beta=5 \mathbf{1}^{\circ} 42^{\prime} .\end{array}$ & 296 & $\begin{array}{l}\text { Aldebaran and } \beta \text { Pegasi } \\
\text { ( } \alpha \text { Pegasi on p. } 296 \text { was } \\
\text { a printer's error). }\end{array}$ \\
\hline
\end{tabular}

Tracing these five apparent orbits on a celestial globe they gave the intersection point above mentioned. It is clear that this point, joined with the eye of the observer, gives the direction of the true path. This point lying further, the globe being placed on the different latitudes and hours, not far from the point E. $20^{\circ} \mathrm{N}$. of the eastern horizon (at Utrecht $7^{\circ}$ above the horizon), it is evident that the lines of intersection, formed by the plane of the mean horizon with the planes of the apparent orbits must be nearly parallel to this direction. That these lines of intersection cannot be true parallels follows from the observations of the four students at Cooper's Hill (p. 97), from that of Mr. Joseph Clark at Street, communicated by Mr. J. E. Clark, at York; and from that of Mr. A. S. P. at Cambridge (p. 87), who saw the phenomenon disappear in the S.W., S.W. and S.S.W. Further the Revue Mensuelle of M. C. Flammarion ( $2^{\text {me }}$ Année, p. 72), containing a short report of Mr. Dupire's observation, mentioned above, gives also an observation made at Ploërmel ( $\beta=47^{\circ} 55^{\prime}, \lambda 2^{\circ} 23^{\prime} \mathrm{W}$. Greenwich), where the phenomenon disappeared in the west.

Now I have drawn a stereographic map on a large scale, and brought the intersection of the vertical plane through Brussels, with the bearing E. $20^{\circ} \mathrm{N}$. It is clear vatoire de Bruxelles, November 18, 1882: "À 6h. 23m. un énorme rayon d'un blanc vif s'éléva à l'horizon E.N.E.; il traversa le ciel en passant le zénith et alla s'éteindre à l'horizon O.S.O." A similar phenomenon has been observed by Dr. F. Terby at Louvain. The great attraction of the Laon observation consisted in the fact that the meteor's apparent path was there seen at the north side of the zenith, tbis being in harmony with the Brussels zenith observation, and promising a good determination of the sought orbit.

In the first place I took the following apparent orbits from the numerous given observations. They can or must be taken as great circles, and must, in this case, fulfil the condition of intersecting one another in two opposite points of the sphere. In fact their intersections are contained within a small space and gave me an approximate position to one of these two points, $a=70^{\circ} 30^{\prime}$, $\delta=+14^{\circ} 30^{\prime}$.

These five apparent orbits, the only ones given completely, are the following :-

\begin{tabular}{|c|c|c|}
\hline $\begin{array}{l}\text { Deduced horizontal } \\
\text { direction. }\end{array}$ & $\begin{array}{l}\text { Local time of max. } \\
\text { elevation. }\end{array}$ & Observer. \\
\hline $\begin{array}{l}\text { E. } 20^{\circ} \text { N.-W. } \\
20^{\circ} \mathrm{S} \text {. (nearly); } \\
\text { deduced by the } \\
\text { ohserver. }\end{array}$ & $6 \mathrm{~h} .4$ or $5 \mathrm{~m}$. & H. D. Taylor. \\
\hline $\begin{array}{l}\text { E. } 20^{\circ} \text { N. }-W . \\
20^{\circ} \mathrm{S} .\end{array}$ & 6h. $4 \mathrm{~m}$. & A. M. Worthington. \\
\hline $\begin{array}{l}\text { E. } 20^{\circ} \text { N. }-W . \\
20^{\circ} \mathrm{S} .\end{array}$ & $6 \mathrm{~h} .6 \mathrm{~m}$. & John L. Dobson. \\
\hline $\begin{array}{l}\text { E. } 20^{\circ} \text { N. }-\mathrm{W} . \\
20^{\circ} \mathrm{S} .\end{array}$ & $6 \mathrm{~h} .24 \mathrm{~m}$. & Prof. J. A. C. Oudemans \\
\hline $\begin{array}{l}\text { E. } 20^{\circ} \text { N. }-W . \\
20^{\circ} \mathrm{S} .\end{array}$ & 6h. $21 \mathrm{~m}$. & P. Zeeman. \\
\hline
\end{tabular}

that the true orbit must lie in the vertical plane. Further I have constructed the angles formed by the planes of the apparent orbits with the respective horizons, correcting, if necessary, for the curvature of the earth, and after much trouble found the following path, being a straight line having the properties given in the table on p. I06, that enables us at the same time to compare the results of my construction with the data of the different observations given in order from $\mathrm{E}$. to $\mathrm{W}$.

I hope that the observers will be content with the degree of harmony between their observations and my results. I believe that a small change in the direction of the orbit's plane will give still more harmony between calculation and observation, but the orbit found satisfies the chief observed facts, and gives the greatest divergence, where the observations bave the smallest sharpness. I believe I have proved by this research that there existed, with the aurora of November 17, I882, cosmic dust, passing through the upper strata of our atmosphere with great velocity, and giving, according to the most interesting observation of $\mathrm{Mr}$. Rand Capron (p. 84), "the usual green line" of the aurora spectrum. Thus nature itself has been so kind as to give an experiment that till now, and perhaps for ever, is beyond human 


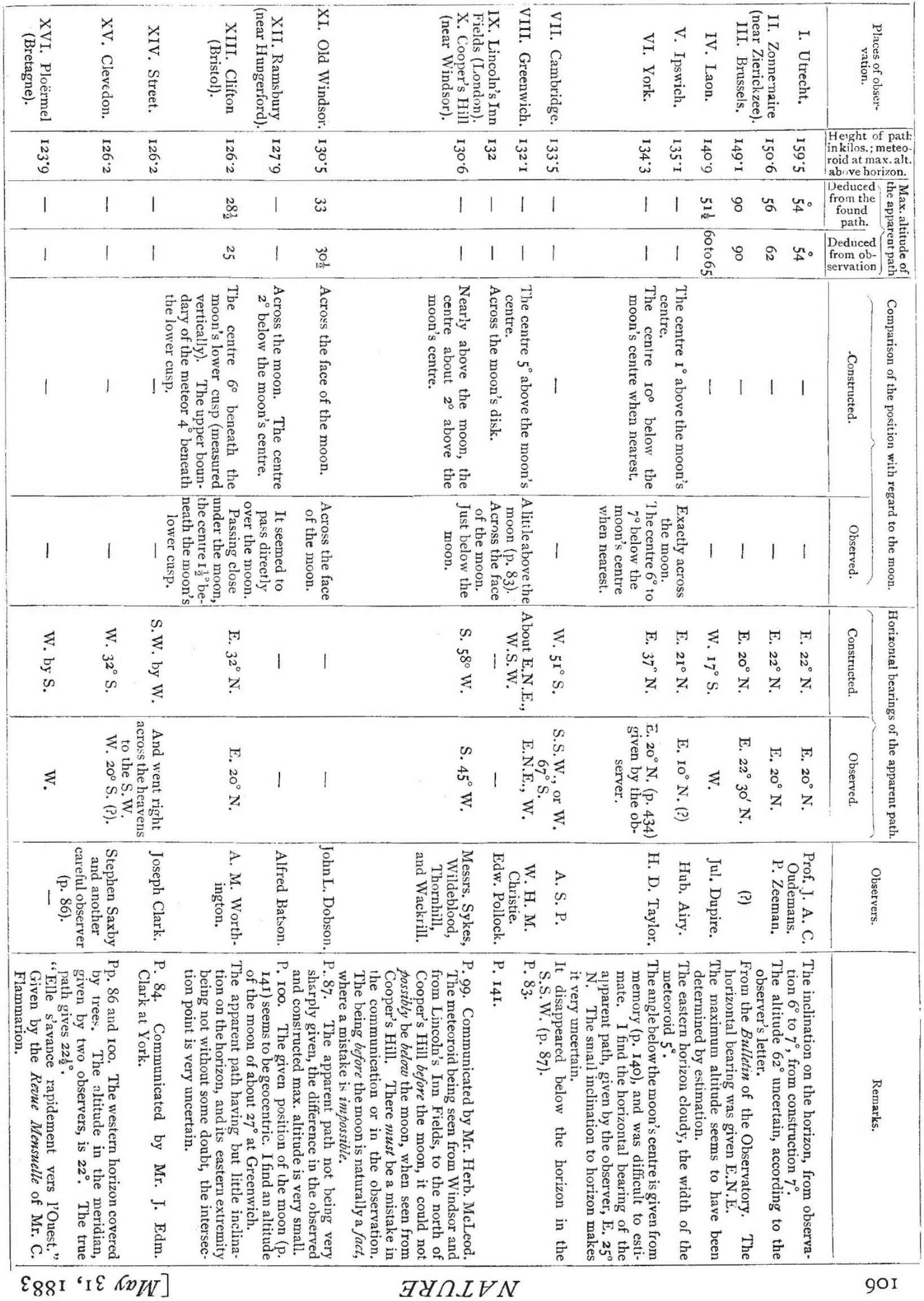


power, for our means are not sufficient to throw projectiles with several thousand metres velocity ; and it is very remarkable that this experiment comes at the same time as the interesting experiment of Prof. Lemström, showing that electric currents are able to give a development of light in our atmosphere, possessing the same number of undulations in a second as the auroral light. Now our meteoroid being a part of an aurora, it gives a stronger proof of the origin of that phenomenon than Prof. Lem. ström's experiment, the greatest attraction of which is that we are able to repeat it arbitrarily and with our own means. Further, I have always maintained that electricity, excited easily by friction, must be one of the causes of the auroral light ("Théorie Cosmique de l'Aurore Polaire," Journal des Spectroscopistes Italiens, 1878 , vol. vii. chap. ii.), and it seems to me very plausible that cosmic matter, approaching the earth, induces electric currents through the air. Therefore I think that the results of Prof. Lemström are in full harmony with the idea of a cosmic origin of auroræ.

The orbit found does not reach the surface of the earth, being at its nearest approach still $123^{\circ} 9$ kilometres (I mile $=1609^{\prime} 3$ metres ; 1 German geogr. mile $=7420^{\circ} 4$ metres) or I6. 7 geogr. miles from that surface. The length of the orbit from the Utrecht perpendicular line to the Utrecht horizon is $1,483,070$ metres, and this line being run over in 60 seconds, ${ }^{1}$ the mean relative velocity was 24,673 metres, 15.3 miles, or more than 3 German geogr. miles.

The dimensions of the "cosmic cloud" (length $40^{\circ}$, width $5^{\circ}$, as seen from Ipswich) are: length $=182,594$, width $=21921$ metres. By these dimensions, probably too great from irradiation, it must show at Utrecht an apparent length of $50^{\circ}$; but the extremities were tapered and therefore the length strongly influenced by the transparency of the air. It is therefore not strange that the apparent length at Utrecht was during some few seconds 90 degrees.

To conclude, I will remark that the proved existence of a cosmic cloud, preserving its pretty sharp sides during so long a path as that from Sweden to the Atlantic Ocean, notwithstanding its velocity of 247 kilometres, proves its particles to be nearly spherical. Otherwise these particles should necessarily have diverged sideways from the orbit and spread into space. In connection with the fact observed by Mr. P. Zeeman (p. 297), that auroral clouds gave interference-phenomena, when coming before the moon's disk, and these latter phenomena requiring (Dagnin, "Traité de Phys.," iv. p. 446) the presence of nearly equal particles of dusty matter, Mr. Zeeman's observation proves the same property in the particles of the auroral cloud. Being nearly equal, but not perfectly, the tangential atmospheric resistance must throw the smallest particles backward, and this explains the oblong shape of the cloud.

In presenting my results and reasonings to the readers of this journal, I hope that they will remember that this paper has been written in a shorter time than the author had wished.

Groningen (Netherlands), April 7

\section{THE AURORA BOREALIS ${ }^{2}$}

\section{II.}

THE Aurora Borealis at Sodankylä.-Although the aurora borealis often appeared with considerable intensity, it did not boast many varieties. It began generally with a faint arc in the northern sky, which soon developed into a sharp arc, with streamers and a kind of luminous "drapery" spreading from east to west. The colour of this luminous drapery was not very changeable, so that the spectroscope only returned the usual yellow-

t This number is stated also by the sharp determination given by the Astronomer Royal, Prof. Christie.

${ }^{2}$ Continued from p. 63 . green line. Generally it was of a yellow-whitish colour, with a slight shade of green.

There was, however, an observation made of far greater interest, viz. that the spectroscopic "reaction," i.e. $\lambda=5569$, on several occasions was returned from every quarter of the horizontal plane, even from the zenith, without any aurora being visible. As this reaction was obtained while the ground was still bare, there can be no question of its being a reflection, but that this place was at the moment within the sphere of an auroral discharge, but of such a weak character that it did not appear in the form of aurora borealis. This observation was therefore precisely similar to the one made in I87 I in Lapland, described above.

These observations were chiefly made by my assistant, Herr Biese, who made another remarkable discovery. Nearly due south-east from the Observatory, he received on several occasions a spectral reaction from a narrow belt of the sky, although no aurora was risible. This ob. servation, which was very difficult to effect, as the eye had to be kept entirely away from all light for fully five minutes before the reaction could be traced, I had myself several opportunities of corroborating. In this direction were situated some mountains 300 metres high, about 30 kilometres distant, and in my opinion the reaction was due to the above-described phosphorescent flames, which were seen around the mountain-tops in Lapland and Spitzbergen. All observations were of course made after every trace of daylight had disappeared.

The Phosphorescent Luminosity.-On several occasions the attention of travellers in the Arctic regions has been attracted to a peculiar soft light or "shine" during the night. But, as the change from day to night is very gradual in the Polar regions, as compared with that of southern climes, a certain amount of exertion of the mind is required in order to take cognisance and retain the features of this phenomenon. As, however, attention has been once drawn to the same, it will always be observed. Already in October I noticed it at Sodankylä, and directer the attention of my assistants to it. I give subjoined some extracts from my diary concerning this phenomenon :-

December 9, 1882.-The Polar night shows sometimes a peculiar phosphorescent "shine" or diffused luminosity, which possesses several phases, but the general character of which is a luminosity of a yellow-white colour, which renders the night as light as the moon with a thick bazy air. I take here the appearance and disappearance of the light on two nights when its intensity was greatest.

On December $6 \mathrm{I}$ was on a journey between C rajärvi and Sodankylä. The phenomenon became then apparent at 7 o'clock p.m. When daylight had completely disappeared, there seemed to remain a faint light in which the outlines of objects around could only with difficulty be discerned. At 7.40 this increased, however, so rapidly that in a few moments every object around stood out clearly in a yellow-white hazy phosphorescent luminosity of quickly-shifting intensity. I had unfortunately no thotometer by me by which I could determine the same. It lasted in this form until about ro o'clock.

December 8, at 5 p.m., I walked from the Observatory to the church near it, in order to observe from its steeple some fire-signals from Oratunturi. On the way, I noticed that a yellow-white luminosity of shifting intensity filled the entire horizon, while twenty minutes after it had increased greatly in intensity, and was now strongest in the north, whence it gradually faded to the soutb, where it had least intensity. Near the horizon it was difficult to discern the stars. Higher up it was, however, easier, and from $60^{\circ}$ to the zenith the sky was clear, of a mauve colour. It was exceedingly interesting to compare the light with the Milky Way. The yellow-white light

${ }^{1}$ [By this term Prof. Lemstromm of course refers to the characteristic line in the spectrum of the aurora. The term might be justified by analogy with the "reacions" characteristic of the presence of the various chemical elements. - ED. 